\title{
Ekstraksi silika yang terkandung dalam limbah abu terbang batu bara
}

\author{
Joice D. S. Caroles*
}

Ilmu Kimia FMIPA, Universitas Negeri Manado, Tondano, 95619, Indonesia

\begin{tabular}{l} 
I N F O A R T I K E L \\
\hline Diterima 1 April 2019 \\
Disetujui 25 April 2019 \\
\\
\hline Key word: \\
coal fly ash, \\
$\mathrm{SiO}_{2}, \mathrm{Al}_{2} \mathrm{O}_{3}, \mathrm{~K}_{2} \mathrm{O}, \mathrm{FeO}$ \\
$\mathrm{Kata} \mathrm{kunci:}_{\text {abu terbang batubara, }}$ \\
$\mathrm{SiO}_{2}, \mathrm{Al}_{2} \mathrm{O}_{3}, \mathrm{~K}_{2} \mathrm{O}, \mathrm{FeO}$ \\
\hline
\end{tabular}

${ }^{*} e$-mail:

joicecaroles@gmail.com

${ }^{*}$ Telp:

081340232816

\begin{abstract}
A B STRACT
Coal fly ash waste contains metal oxides, one of which is silica. The presence of silica in coal fly ash allows such waste to be used directly as an adsorbent. The utilization of silica contained in coal fly ash can be carried out optimally with silica purification. Silica purification by extracting silica from coal fly ash aims to minimize unnecessary metal oxide content (impurities). Analysis of silica content performed before and after the extraction process aims to determine the silica content compared with other metal oxides. The procedure is to isolate the sample from the impurity material, then analyse using SEM-EDS instrument, and then proceed with the silica extraction process. The results showed that the percentage of silica (SiO2) content was 67,68\% more than Al2O3 16,80\%; While the content of silica extracted to $80.42 \%$.
\end{abstract}

\section{Pendahuluan}

Perkembangan industri yang semakin pesat membutuhkan bahan bakar sebagai sumber energi untuk terlaksananya kegiatan produksi. Sumber energi yang efisien dan telah banyak digunakan oleh industri adalah batubara. Penggunaan bahan bakar batubara akan menghasilkan abu terbang (fly ash) yang berada pada ruang penangkapan dengan sistem electrostatic precipitator. Abu terbang batubara ini dikategorikan sebagai limbah hasil pembakaran batubara. Limbah tersebut dibiarkan tertumpuk di lingkungan industri.
Penumpukan limbah yang terakumulasi akan menyebabkan dampak buruk terhadap lingkungan karena bersifat ringan, mudah terbawa oleh angin ke sistem udara terbuka sehingga dapat menyebabkan pencemaran lingkungan. Pengolahan berupa pemanfaatan abu terbang batubara ini sebagai bahan adsorben; bahan dasar pembuatan plastik HDPE; bahan sintesis silika mesopori, MCM-41, Faujasite, zeolite; dan secara umum digunakan sebagai bahan tambahan campuran semen[1-5] dapat meminimalisir dampak buruk terhadap lingkungan. 
Abu terbang batubara merupakan limbah hasil pembakaran batubara yang mengandung oksida logam seperti $\mathrm{SiO}_{2}, \mathrm{Al}_{2} \mathrm{O}_{3}$, $\mathrm{Fe}_{2} \mathrm{O}_{3}, \mathrm{CaO}, \mathrm{MgO}, \mathrm{K}_{2} \mathrm{O}, \mathrm{Na}_{2} \mathrm{O}$ [6]. Kadar oksida terbanyak dalam abu terbang batubara adalah $\mathrm{SiO}_{2}\left(60-70 \%\right.$ berat) selain $\mathrm{Al}_{2} \mathrm{O}_{3}$ dan $\mathrm{Fe}_{2} \mathrm{O}_{3}$ [7]. Keberadaan silika terbanyak dibandingkan oksida logam lainnya dalam abu terbang batubara ini memungkinkan untuk dimanfaatkan sebagai adsorben. Pemanfaatan silika dalam abu terbang batubara telah dilakukan untuk mengadsorbsi logam $\mathrm{Cd}$ dan $\mathrm{Pb}[8,9]$.

Silika $\left(\mathrm{SiO}_{2}\right)$ sebagai material adsorben yang digunakan berasal dari silika komersial. Studi tentang kemungkinan ketersediaan silika dalam material alami seperti abu batubara, sekam padi, pasir silika, mendorong eksplorasi komposisi silika dalam material alami tersebut[4, 5, 10]. Umumnya material alami yang mengandung silika dimanfaatkan langsung sebagai adsorben, namun kerja silika sebagai adsorben belum maksimal oleh karena adanya oksida logam lain sebagai pengotor yang mendekati atau hampir sama komposisinya dengan silika. Upaya untuk memaksimalkan kerja silika sebagai adsorben dilakukan dengan cara meminimalkan pengotor yang terdapat bersama dengan silika. Silika dengan kemurnian tinggi dapat diperoleh dengan metode pencucian menggunakan larutan asam dan diekstraksi dengan metode alkali fusi [1]. Kandungan Silika yang besar pada CFA dapat dimanfaatkan sebagai pendukung fotokatalis $\mathrm{TiO}_{2}$ dan diaplikasikan untuk menurunkan konsentrasi logam berat pada limbah [11].

\section{Bahan dan Metode}

Bahan-bahan yang digunakan dalam penelitian ini adalah abu terbang batubara, akuades dan asam klorida.Alat-alat yang digunakan dalam penelitian ini adalah peralatan gelas laboratorium, pengayak 270 mesh, oven, kertas saring whatman no 42, corong Buchner dan $\mathrm{pH}$ meter.

Preparasi abu terbang untuk analisis kandungan silika dilakukan dengan cara pengayakan abu terbang batubara menggunakan pengayak 270 mesh, kemudian dianalisis dengan SEM-EDS.

\section{Ekstraksi $\mathrm{SiO}_{2}$ dari CFA}

Proses ekstraksi diawali dengan pengayakan Sejumlah CFA yang kemudian ditambahkan dengan larutan $\mathrm{HCl} 1 \mathrm{M}$ (1:5 $\mathrm{g} / \mathrm{mL}$ ) dan dipanaskan pada suhu $90^{\circ} \mathrm{C}$ selama 4 jam. Endapan yang terbentuk dinetralkan dengan akuades dan dikeringkan pada suhu $110^{\circ} \mathrm{C}$ selama $12 \mathrm{jam}$.

Coal fly ash hasil pencucian dengan $\mathrm{HCl}$ ditambahkan ke dalam larutan $\mathrm{NaOH} 3 \mathrm{M}$ dan dipanaskan pada suhu $90^{\circ} \mathrm{C}$ selama 4 jam. Filtrat yang dihasilkan kemudian ditambahkan larutan $\mathrm{HCl}$ perbandingan (1:1) terhadap aquadest sambil diaduk hingga terbentuk endapan putih ( $\mathrm{pH}$ 4). Endapan putih dicuci dengan aquadest hingga $\mathrm{pH}$ pencucian netral. Endapan dipanaskan dalam oven dengan suhu $110^{\circ} \mathrm{C}$ selama 12 jam.

\section{Hasil dan Pembahasan}

Tahap awal dimulai dengan pengayakan CFA yang bertujuan untuk menyaring CFA dari pengotor-pengotor, menyeragamkan ukuran partikel dan memperbesar luas permukaan CFA untuk membuat kontak antara $\mathrm{CFA}$ dengan $\mathrm{HCl}$ semakin banyak terjadi pada saat proses pencucian CFA sehingga proses pelarutan logam-logam pengotor berlangsung cepat.

Proses pencucian dengan asam dapat melarutkan logam-logam dalam CFA sehingga mengurangi komposisi oksida-oksida logam yang tidak diperlukan. Pengurangan kadar oksida-oksida logam tersebut berdampak pada peningkatan kandungan $\mathrm{SiO}_{2}$ CFA. Tabel 1 menunjukkan terjadi penurunan kadar logam Aluminium yang berdampak pada peningkatan kadar silika sebesar 13\%.

Proses selanjutnya setelah pencucian CFA yaitu ekstraksi $\mathrm{SiO}_{2}$ dari larutan natrium silikat yang terbentuk dari pemanasan CFA dengan larutan $\mathrm{NaOH} 3 \mathrm{M}$ dengan persamaan reaksi :

$\mathrm{SiO}_{2}(s)+2 \mathrm{NaOH}(a q) \rightarrow \mathrm{Na}_{2} \mathrm{O} . x \mathrm{SiO}_{2}(a q)+\mathrm{H}_{2} \mathrm{O}(l)$

Campuran larutan silikat dengan asam encer menghasilkan gelatin $\mathrm{SiO}_{2} . x \mathrm{H}_{2} \mathrm{O}$ yang disebut asam silikat.

$\mathrm{Na}_{2} \mathrm{SiO}_{3}(a q)+2 \mathrm{HCl}(l)+\mathrm{H}_{2} \mathrm{O}(l) \rightarrow \mathrm{Si}(\mathrm{OH})_{4}(a q)+$ 
$2 \mathrm{NaCl}(a q)$

Larutan natrium silikat bersifat basa (pH 11-12). Penambahan $\mathrm{HCl}$ akan membentuk gugus siloksan (Si-O-Si) sehingga dihasilkan silika gel.

Setelah silika terekstraksi, selanjutnya dilakukan analisis menggunakan SEM-EDS. Dari hasil EDS diperoleh kandungan $\mathrm{SiO}_{2}$ yang diekstraksi dari CFA adalah sebesar 80,42\%. Perbedaan kandungan silika sebelum dan sesudah ekstraksi, disajikan pada Tabel 1.

Tabel 1. Perbandingan Kandungan Silika

\begin{tabular}{ccc}
\hline \multirow{2}{*}{ Komponen } & \multicolumn{2}{c}{ Persentase Massa } \\
\cline { 2 - 3 } & $\begin{array}{c}\text { Sebelum } \\
\text { ekstraksi }\end{array}$ & $\begin{array}{c}\text { Setelah } \\
\text { ekstraksi }\end{array}$ \\
\hline $\mathrm{Al}_{2} \mathrm{O}_{3}$ & 16,80 & 4,48 \\
$\mathrm{SiO}_{2}$ & 67,68 & 80,42 \\
\hline
\end{tabular}

\section{Kesimpulan}

Kandungan silika yang diperoleh setelah ekstrasi dengan pencucian menggunakan asam klorida, memberikan hasil sebesar $80,42 \%$.

\section{Daftar Pustaka}

1. Jha, B.; Padmakumar, G. P.; Singh, D. N.; Iyer, K. In Synthesis of zeolites by fly ash alkali interaction, 2011, 2011; pp 1089-1092.

2. Kusumawati, E. N.; Ediati, R. Sintesis MCM-41 menggunakan sumber silika dari abu layang batubara PLTU Paiton dengan variasi suhu dan waktu hidroternal. http://digilib.its.ac.id.

3. Lee, K. T.; Bhatia, S.; Mohamed, A. R., Preparation and characterization of sorbents prepared from ash (waste material) for sulfur dioxide (SO 2) removal. Journal of material cycles and waste management 2005, 7, (1), 16-23.

4. Misran, H.; Kamarudin, R. A.; Zakaria, M. S.; Singh, R., Synthesis of mesoporous silica and zeolite phase transformation of coal fly ash from kapar power plant. Solid State Science and Technology 13, (1 \& 2), 216-225.

5. Sutarno, S.; Arryanto, Y.; Budhyantoro, A., Sintesis Faujasite dari abu layang batubara: Pengaruh Refluks dan Penggerusan Abu
Layang Batubara terhadap Kristalinitas Faujasite. Jurnal Matematika E Sains 2009, 9, (3), 285-290.

6. Dhokte, A. O.; Khillare, S. L.; Lande, M. K.; Arbad, B. R., Synthesis, characterization of mesoporous silica materials from waste coal fly ash for the classical Mannich reaction. Journal of Industrial and Engineering Chemistry 2011, 17, (4), 742-746.

7. Bada, S. O.; Potgieter-Vermaak, S., Evaluation and treatment of coal fly ash for adsorption application. Leonardo Electronic Journal of Practices and Technologies 2008, 12, 37-48.

8. Woolard, M., The use of a modified fly ash as an adsorbent for lead. Water $S A$ 2000, 26, (4), 531-536.

9. Wardani, R. K. Pemanfaatan abu bawah batubara (Bottom Ash) teraktivasi sebagai adsorben in logam Cd2+. Skripsi, Universitas Airlangga, Surabaya, 2012.

10. Kalapathy, U.; Proctor, A.; Shultz, J., A simple method for production of pure silica from rice hull ash. Bioresource Technology 2000, 73, (3), 257-262.

11. Maryani, Y., Degradasi Surfaktan Anionik sebagai Senyawa Aktif Detergen secara Fotokatalisis. UNPAD Press: Bandung. 